\title{
Lineament mapping and geological history of the Kangerlussuaq region, southern West Greenland
}

\author{
Knud Erik S. Klint, Jon Engström, Andrew Parmenter, Timo Ruskeeniemi, \\ Lillemor Claesson Liljedahl and Anne Lehtinen
}

How could future ice ages affect deep nuclear waste repositories in crystalline basement rocks? Deep repositories may be affected by a number of glacially induced processes including, but not limited to, (1) fault activation or re-activation and associated seismicity, (2) changing hydraulic and chemical groundwater dynamics and (3) enhanced erosion. Such processes are likely to affect not only man-made barriers in spent fuel repositories such as copper canisters and bentonite clay buffers, but also the rock masses that contain and isolate the repositories. In order to increase our understanding of this problem, an international study (the Greenland Analogue Project) was set up in 2008. The aim of the study was to use crystalline bedrock at the margin of the Inland Ice near Kangerlussuaq airport in West Greenland as an analogue for future nuclear fuel waste repositories affected by glaciation in Fennoscandia and Canada. Accordingly, a wide range of field surveys were conducted for the analogue project (Fig. 1). This paper describes a detailed structural investigation of lineament zones and the establishment of an event succession for fault and fracture zone evolution in central parts of the study area (Figs 1B, 2), as well as an interpretation of the distribution of fracture and fault zones with potentially increased permeability. Three deep holes were drilled in the study area, and instruments were installed in two of them for subsequent down-hole sampling and monitoring of groundwater to a depth of $c .600 \mathrm{~m}$. The cores were used to compare the subsurface fracture patterns with those established on the basis of surface mapping.

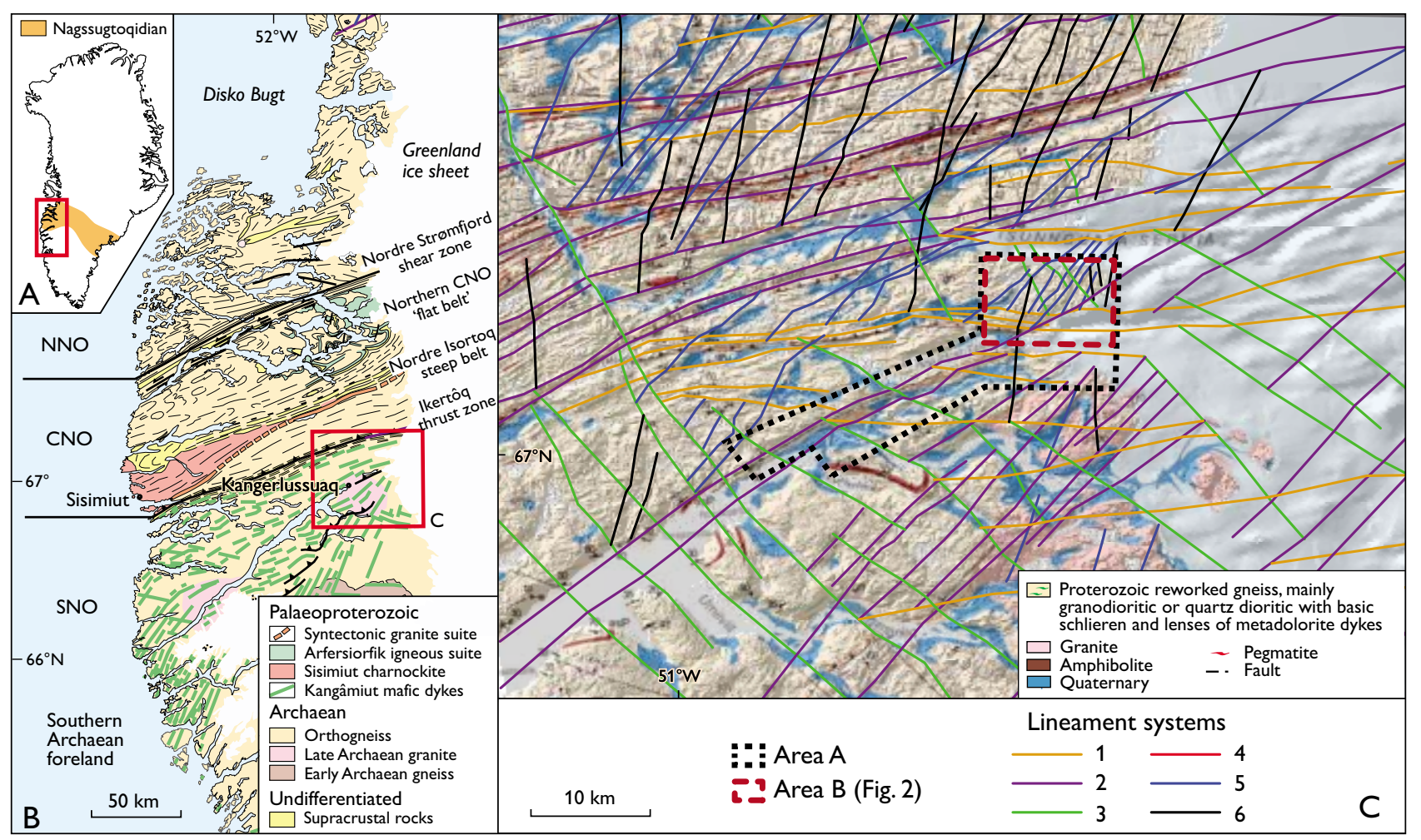

Fig. 1. A: Map of Greenland showing the extent of the Nagssugtoqidian orogen and the location of Fig. 1B (rectangle). B: Regional geology of southern West Greenland, modified from Garde \& Hollis (2010) and Garde \& Marker (2010). CNO, NNO and SNO are central, northern and southern Nagssugtoqidian orogen, respectively. C: Lineament map of the area around Kangerlussuaq airport. Areas A and B were mapped in detail. 


\section{Geological setting}

The Kangerlussuaq area is located close to the southern margin of the $c .1 .85 \mathrm{Ga}$ old collisional Nagssugtoqidian orogen (van Gool et al. 2002). The study area covers a $100 \times 50 \mathrm{~km}$ large area in front of and below the western margin of the Inland Ice (Fig. 1). Detailed geological mapping was carried out along a transect from Kangerlussuaq airport to the margin of the Inland Ice, and of a smaller area around the three drilling sites in the valley in front of the Inland Ice (Fig. 2).

The bedrock is mainly reworked Archaean orthogneiss with minor Palaeoproterozoic metavolcanic amphibolite and metasedimentary rocks that were deformed under highgrade metamorphic conditions during the Nagssugtoqidian orogeny (van Gool et al. 2002). The Nagssugtoqidian structures are generally ductile and include a penetrative gneissic fabric, macroscale folds and pronounced shear zones. Oc- casional, deformed mafic dykes also occur, mainly members of the rift-related Nagssugtoqidian Kangâmiut dyke swarm that preceded the Nagssugtoqidian orogeny (Mayborn \& Lesher 2006). Brittle structures such as faults and fractures are abundant and were probably formed in a younger, shallower, colder and hence more rigid environment.

\section{Regional lineament mapping and geology of the study area}

Most lineaments in crystalline rocks represent structural features such as faults and shear zones, rock fabrics and lineaments that were created at discontinuities due to differences in rheology or competence. Our lineament mapping comprised four steps. First, lineaments were identified using remotely sensed GIS-data compiled from aerial photographs,

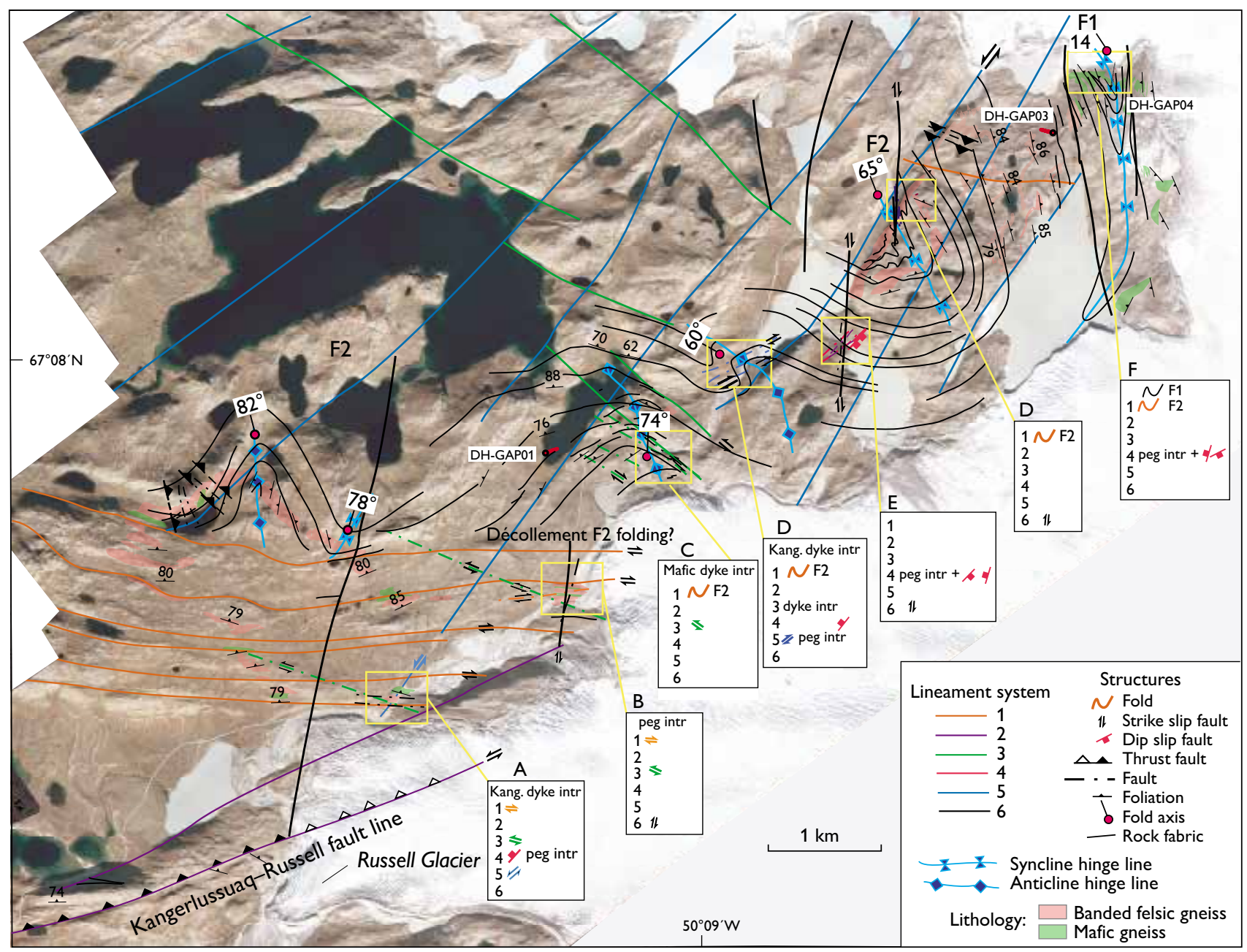

Fig. 2. Aerial image of area B (Fig. 1C) with mapped and inferred rock fabric (foliation), rock types and structural elements. Local event stratigraphic models were developed for locations A-F. The macro-scale structures outline large-scale ductile folds overprinted by various shear and fault zones. Three deep holes were drilled (DH-GAP01, DH-GAP03 and DH-GAP04). 
Table 1. Event succession of the Kangerlussuaq area compared with the general history of central West Greenland*

\begin{tabular}{|c|c|c|}
\hline Age & General tectonic events in central West Greenland & Correlation to the Kangerlussuaq area \\
\hline$>2.5 \mathrm{Ga}$ (Archaean) & Formation of 'banded gneiss' protoliths & F1 folding + multiple healed structures \\
\hline c. $2.04 \mathrm{Ga}$ & Continental rifting coupled with mafic dyke intrusions & Intrusion of Kangâmiut mafic dykes \\
\hline $1.92-1.75 \mathrm{Ga}$ & $\begin{array}{l}\text { Nagssugtoqidian orogen. Continental collision. Reworking, } \\
\text { folding and thrusting of gneiss/mafic rocks followed by } \\
\text { peak metamorphism and large-scale folding during N-S } \\
\text { contraction. Finally formation of steep belts with sinistral } \\
\text { movements }\end{array}$ & $\begin{array}{l}\text { System } 1 \text { dextral, strike-slip shear and F2 folding } \\
\text { System } 2 \text { WSW-ENE-trending faulting }\left(\mathrm{K}-\mathrm{R} \mathrm{fl}^{\dagger}\right) \\
\text { Reactivation of Kangerlussuaq-Russell fault sinistral } \\
\text { strike slip } \\
\text { System } 3 \text { sinistral strike-slip shear zones }\end{array}$ \\
\hline c. 1.78 to present day & $\begin{array}{l}\text { Various stress conditions. Formation and reactivation } \\
\text { of open mode fractures at more shallow depths during } \\
20-25 \mathrm{~km} \text { uplift }\end{array}$ & $\begin{array}{l}\text { System } 4 \text { normal faults with shallow dip towards } \\
\text { SE and NW accompanied by pegmatite intrusions }\end{array}$ \\
\hline $1.2 \mathrm{Ga}$ & $\begin{array}{l}\text { Diamond-bearing, ultramafic lamprophyre intrusions } \\
\mathrm{S} \text { and } \mathrm{W} \text { of Kangerlussuaq }\end{array}$ & \\
\hline $600 \mathrm{Ma}$ & Kimberlite intrusions $\mathrm{S}$ and $\mathrm{W}$ of Kangerlussuaq & \\
\hline $100-50 \mathrm{Ma}$ & $\begin{array}{l}\text { Faulting related to sea-floor spreading during the } \\
\text { opening of Labrador Sea and Baffin Bay. NNE-SSW } \\
\text { sinistral strike-slip faulting and conjugate dextral strike- } \\
\text { slip faulting }\end{array}$ & $\begin{array}{l}\text { System } 5 \text { sinistral strike-slip faults trending NE-SW } \\
\text { System } 6 \text { dextral strike-slip faults trending N-S }\end{array}$ \\
\hline At least the last $2 \mathrm{Ma}$ & $\begin{array}{l}\text { Repeated glaciations resulting in erosion, glacier-induced } \\
\text { reactivation of fractures during glacial subsidence and } \\
\text { rebound of the basement }\end{array}$ & Reactivation of existing fault zones \\
\hline
\end{tabular}

* based on van Gool et al. (2002) and Garde \& Hollis (2010)

† Kangerlussuaq-Russell fault line

topographical and geological maps and geophysical data. The second step was a descriptive and kinematic field analysis of the remotely detected lineaments. In the third step, a local event succession model was developed by determination of overprinting relationships. Finally, the local geological history of the Kangerlussuaq area was interpreted and correlated with the regional geological evolution (van Gool et al. 2002; Garde \& Hollis 2010).

In order to provide an overview of the geological framework of the study area, the measured and interpreted structures (foliation, fold hingeline, fault and shear zone traces) are shown on a high-resolution aerial image (Fig. 2). Close to the margin of the Inland Ice in the north-eastern part of the area, the bedrock is characterised by folded mafic gneiss that defines an open, NNW-trending and shallowly plunging $\left(c .14^{\circ}\right) \mathrm{F} 1$ fold structure. This structure gradually turns into a tight to isoclinal fold that can be traced southward and westward around an open, steeply-plunging, kilometre-scale F2 fold structure with a NW- to N-trending axial surface (Figs 1C, 2).

Five general lineament systems were outlined from the GIS analysis, and a sixth, subhorizontal system was identified by the field work, during which also the curvilinear nature of the foliation traces became apparent and highlighted the superposition of the F1 and F2 fold phases. On a regional scale, system 1 lineaments are generally distributed between the system 2 steep belts (Fig 1). These lineaments dominate in some parts of the southern study area and consist of ductile,
E-W-trending, 10-100 m wide, foliation-parallel, steeply inclined and steeply $\mathrm{N}$-dipping dextral shear zones (Figs 1C, 2). These shear zones may have acted as décollement planes for the F2 folding (see below).

System 2 lineaments constitute the most pronounced linear feature and represent regional, SW-trending shear zones, including the zone outlining Søndre Strømfjord itself and especially the northern margin of Sandflugtdalen that extends from Kangerlussuaq to Russell Glacier, hereafter named the Kangerlussuaq-Russell fault line. Other lineaments farther north with similar orientations (Fig. 1B) comprise the Ikertôq zone (van der Molen 1984), the Nordre Isortoq steep belt and the Nordre Strømfjord shear zone (van Gool et al. 2002). Along the Kangerlussuaq-Russell fault line this lineament is dominated by sinistral strike-slip movement overprinting elements of thrust faulting dipping towards the north. Large boudins of deformed Kangâmiut mafic dykes (Mayborn \& Lesher 2006) are included in this zone, which is therefore younger than the intrusion of the Kangâmiut dykes.

System 3 lineaments are a major NW-trending system along pronounced valleys and extend all the way up to Aassiaat and Disko Bugt (Fig. 1A). Locally within the study area they form semi-brittle, sinistral strike-slip fault zones that displace the system 1 shear zones.

System 4 lineaments form oblique to sub-horizontal fracture systems trending NNE and are not represented by any pronounced topographic lineaments. These structures may also be related to a population of normal faults and younger, 
NNE-trending pegmatites orientated parallel with the normal faults. They overprint the system 1 and 3 lineaments, but no cross-cutting relations to system 2 lineaments have been noticed.

System 5 lineaments are semi-brittle, sinistral, strike-slip faults trending NE and dipping to the NW. This system outlines the pronounced escarpment in the central to northeastern part of the study area (Fig. 2). Local zones of WSWstriking thrust faults with both northerly and southerly dips are regarded as representing local transpression in a wrench fault system related to the overall system 5 lineaments.

System 6 lineaments consist of N-S-trending, brittle, dextral, strike-slip faults. This system may be conjugate with system 5. Lineaments with this orientation near the outer coast of central West Greenland have been related to the rifting between Greenland and Canada during the last $100 \mathrm{Ma}$ (Wilson et al. 2006).

\section{Preliminary geological history}

As demonstrated by its structural complexity (Fig. 2), the study area has undergone several episodes of deformation. These episodes have been compiled into a local event history that recognises seven types of structural overprint ( $\mathrm{Ta}$ ble 1). Two stages of folding (F1 and F2) are identified. F1 may be of Archaean age, while F2 seems to be Nagssugtoqidian and contemporary with the system 1 shear zones, since the Kangâmiut dykes were folded during this event. The Kangerlussuaq-Russell fault line of system 2 lineaments has been reactivated with sinistral, strike-slip movement, during which the Kangâmiut dykes were deformed, but a clear, cross-cutting relation with systems 1 and 3 has not yet been documented. The system 3 lineaments clearly overprint system 1 and the F2 folds. The normal faulting and NNEtrending pegmatites of system 4 either indicate a general, extensional stress regime or local transtension during strikeslip movements. The timing of this event is highly speculative. The youngest geological events are related to the type 5 and 6 lineaments that form two, generally brittle, strike-slip fault systems. These are also regarded as the primary hydraulic zones in the Kangerlussuaq area.

The absolute ages of the different types of ductile and brittle deformation are uncertain because of lack of radiometric ages. However, in relative terms, it is suggested that the Kangerlussuaq-Russell fault line and most other semi-ductile shear zones are ancient features related to the Nagssugtoqidian orogeny (van Gool et al. 2002). The system 3 and 4 semi-brittle lineaments may be of intermediate ages related to postorogenic tectonic events, whereas the youngest and most brittle deformations may be related to the opening of the North Atlantic Ocean, the Labrador Sea and the Baffin Bay over the last $100 \mathrm{Ma}$ (Wilson et al. 2006).

\section{Acknowledgement}

The study was funded by the Swedish, Finnish and Canadian nuclear waste management organisations.

\section{References}

Garde, A.A. \& Hollis, J.A. 2010: A buried Palaeoproterozoic spreading ridge in the northern Nagssugtoqidian orogen, West Greenland. Geological Society Special Publications (London) 338, 213-234.

Garde, A.A. \& Marker, M. 2010: Geological map of Greenland, 1:500 000, Søndre Strømfjord - Nuussuaq. Copenhagen: Geological Survey of Denmark and Greenland.

Mayborn, K.R. \& Lesher, C.E. 2006: Origin and evolution of the Kangâmiut mafic dyke swarm, West Greenland. In: Garde, A.A. \& Kalsbeek, F. (eds): Precambrian crustal evolution and Cretaceous-Palaeogene faulting in West Greenland. Geological Survey of Denmark and Greenland Bulletin 11, 61-86.

van Gool, J.A.M., Connelly, J.N., Marker, M. \& Mengel, F.C. 2002: The Nagssugtoqidian orogen of West Greenland: tectonic evolution and regional correlations from a West Greenland perspective. Canadian Journal of Earth Sciences 39, 665-686.

van der Molen, I. 1984: Dykes and deformation in the Ikertôq zone of the Nagssugtoqidian at Søndre Strømfjord Airport, West Greenland. Bulletin of the Geological Society of Denmark 32, 101-106.

Wilson, R.W., Klint, K.E.S., van Gool, J.A.M., McCaffrey, K.J.W., Holdsworth, R.E. \& Chalmers, J.A. 2006: Faults and fractures in central West Greenland: onshore expression of continental break-up and seafloor spreading in the Labrador - Baffin Bay Sea. Geological Survey of Denmark and Greenland Bulletin 11, 185-204.

\footnotetext{
Authors' addresses

K.E.S.K., Geological Survey of Denmark and Greenland, Øster Voldgade 10,DK-1350 Copenhagen K, Denmark. E-mail: kesk@geus.dk

J.E. \& T.R., Geological Survey of Finland, P.O. Box 96, SF-02151 Espoo, Finland.

L.C.L., Swedish Nuclear Fuel and Waste Management Co, Box 250, SE-101 24, Stockholm, Sweden.

A.P., Nuclear Waste Management Organization, 22 St. Clair Avenue East, Sixth Floor, Toronto, M4T 2S3, Canada.

A.L., Posiva Oy Olkiluoto, SF-27160 Eurajoki, Finland.
} 